\title{
Epstein-Barr Virus-Positive Mucocutaneous Ulcer: A Unique and Curious Disease Entity
}

\author{
Tomoka Ikeda $^{1}{ }^{\mathbb{D}}$, Yuka Gion ${ }^{2}$, Yoshito Nishimura ${ }^{3} \mathbb{D}$, Midori Filiz Nishimura $^{1} \mathbb{D}$, Tadashi Yoshino ${ }^{1}$ \\ and Yasuharu Sato $1,2, *$ (D)
}

Citation: Ikeda, T.; Gion, Y.; Nishimura, Y.; Nishimura, M.F.; Yoshino, T.; Sato, Y. Epstein-Barr Virus-Positive Mucocutaneous Ulcer: A Unique and Curious Disease Entity. Int. J. Mol. Sci. 2021, 22, 1053.

https://doi.org/10.3390/ijms22031053

Academic Editor: Anna Aiello

Received: 13 January 2021

Accepted: 19 January 2021

Published: 21 January 202

Publisher's Note: MDPI stays neutral with regard to jurisdictional claims in published maps and institutional affiliations.

Copyright: (C) 2021 by the authors Licensee MDPI, Basel, Switzerland. This article is an open access article distributed under the terms and conditions of the Creative Commons Attribution (CC BY) license (https:// creativecommons.org/licenses/by/ $4.0 /)$.
1 Department of Pathology, Okayama University Graduate School of Medicine, Dentistry and Pharmaceutical Sciences, Okayama 700-8558, Japan; me421004@gmail.com (T.I.); p2hq21br@s.okayama-u.ac.jp (M.F.N.); yoshino@md.okayama-u.ac.jp (T.Y.)

2 Division of Pathophysiology, Okayama University Graduate School of Health Sciences, Okayama 700-8558, Japan; gion@okayama-u.ac.jp

3 Department of General Medicine, Okayama University Hospital, Okayama 700-8558, Japan; nishimura-yoshito@okayama-u.ac.jp

* Correspondence: satou-y@okayama-u.ac.jp; Tel.: +81-86-235-7150; Fax: +81-86-235-7156

\begin{abstract}
Epstein-Barr virus (EBV)-positive mucocutaneous ulcer (EBVMCU) was first described as a lymphoproliferative disorder in 2010. EBVMCU is a unifocal mucosal or cutaneous ulcer that often occurs after local trauma in patients with immunosuppression; the patients generally have a good prognosis. It is histologically characterized by proliferating EBV-positive atypical B cells accompanied by ulcers. On the basis of conventional pathologic criteria, EBVMCU may be misdiagnosed as EBVpositive diffuse large B-cell lymphoma or other lymphomas. However, its prognosis differs from that of EBV-associated lymphomas, in that patients with EBVMCU frequently show spontaneous regression or complete remission without chemotherapy. Therefore, EBVMCU is now recognized as a low-grade malignancy or a pseudo-malignant lesion. Avoiding unnecessary chemotherapy by distinguishing EBVMCU from other EBV-associated lymphomas will reduce the burden and unnecessary harm on patients. On the basis of these facts, EBVMCU was first described as a new clinicopathological entity by the World Health Organization in 2017. In this review, we discuss the clinicopathological characteristics of previously reported EBVMCU cases, while focusing on up-to-date clinical, pathological, and genetic aspects.
\end{abstract}

Keywords: EBV-positive mucocutaneous ulcer; clinical features; pathological features; immunosuppression

\section{Introduction}

Epstein-Barr virus (EBV) is a member of the herpes virus family, and is one of the most common human viruses [1]. EBV causes latent infection in humans and it may lead to various diseases, including lymphomas and lymphoproliferative disorders (LPDs) even during the latency period. EBV-positive mucocutaneous ulcer (EBVMCU) is a recently established EBV-associated LPD, established in 2010. EBVMCUs are shallow, sharply circumscribed, mucosal, or cutaneous ulcers that are histologically characterized by the proliferation of EBV-positive, variable-sized, atypical B-lymphocytes. This lesion develops in immunocompromised patients, including those who are of advanced age or have iatrogenic immunosuppression, primary immune disorders, or human immunodeficiency virus (HIV)/acquired immunodeficiency syndrome (AIDS)-associated immune deficiencies. EBVMCU has a good prognosis, unlike other EBV-associated LPDs such as EBV-positive diffuse large B-cell lymphoma (DLBCL). Almost all EBVMCU patients achieve remission with the reduction or discontinuation of immunosuppressants, or a watch-and-wait approach. In this review, we discuss the clinical, pathological, and genetic aspects of EBVMCU. 


\section{EBV Biology}

EBV, also known as human herpesvirus 4 [2-6], is a ubiquitous virus with a 172 kilobase double-stranded DNA genome [7]. EBV infects both human B lymphocytes and epithelial cells and is transmitted via saliva; therefore, $90 \%$ of children get infected with EBV before the age of 5 years. Most people remain asymptomatic, except for those who develop infectious mononucleosis [8,9].

EBV preferentially infects B lymphocytes via engagement between gp350, a viral surface glycoprotein, and its primary receptor on B lymphocytes, that is, complement receptor 2 (CR2/CD21), or CR1 (CD35). gH/gL/gp42, another viral glycoprotein, binds the class II major histocompatibility complex molecules on B lymphocytes, which function as coreceptors. While people may have EBV chronically, it rarely causes clinically significant problems (Table 1).

Table 1. EBV-associated disorders.

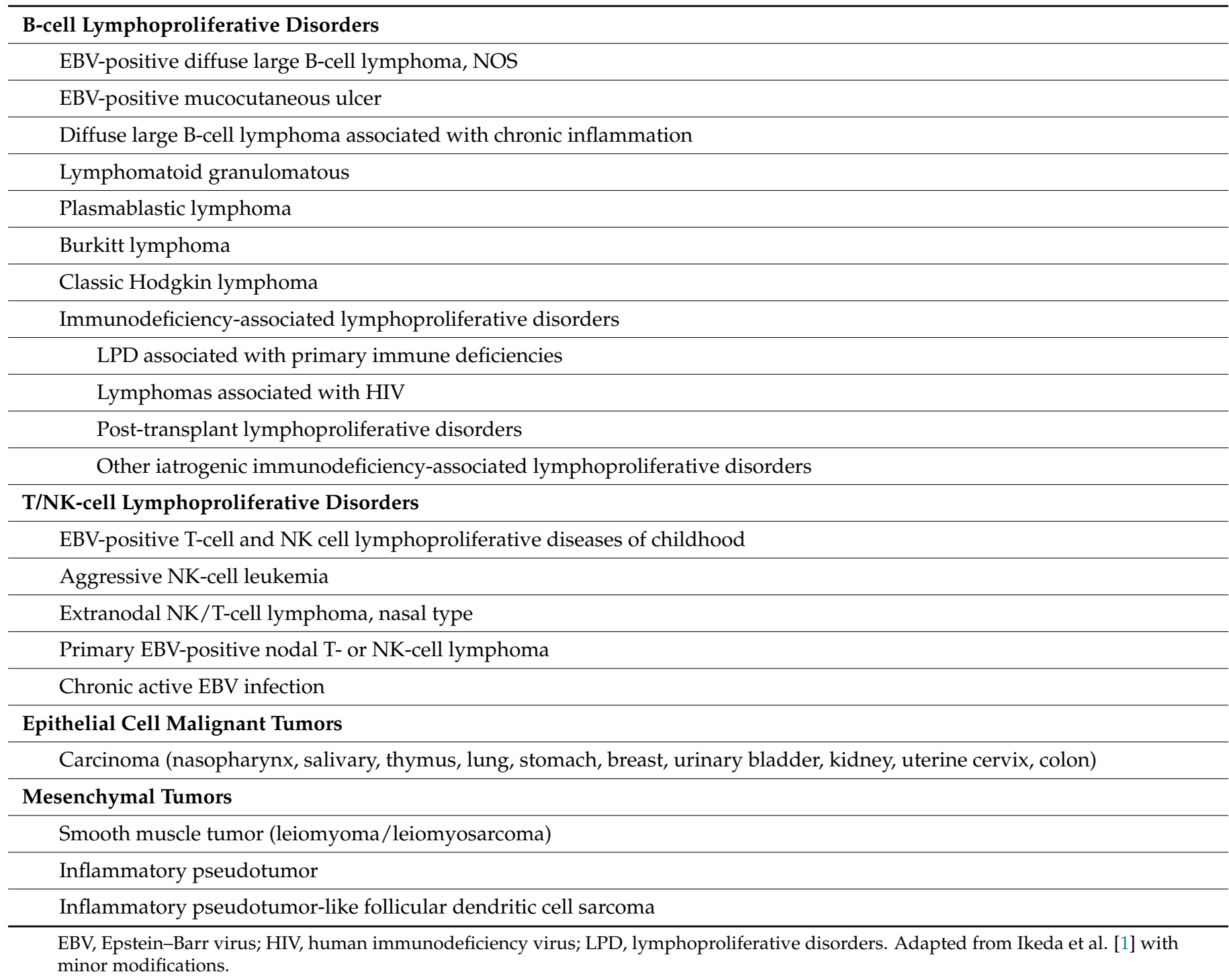

EBV evades the host immune response by reducing the frequency of viral gene transcription; however, the exact mechanism underlying immune evasion has not yet been elucidated. EBV infection has two phases: a lytic phase and a latent phase. During the lytic phase, the orally transmitted virus replicates in oropharyngeal epithelial cells. The viral genome is then maintained in the host oropharyngeal lymphoid tissue cells during the latent phase. EBV gene products upregulate the expression of various host B cell genes. 
EBV produces EBV nuclear antigen (EBNA) and latent membrane protein (LMP) gene products during latency. These include EBNA1, EBNA2, EBNA3A, EBNA3B, EBNA3C, EBNA leader protein, LMP1, and LMP2, which mediate the transforming role of EBV in B cells [10].

The latency phase has three subphases, which are defined by the viral gene expression pattern: Latency I, II, and III. In Latency I, EBV expresses only EBNA1, which is present in all infected cells. Viral genome maintenance and replication occur during this phase. Latency II is an intermediate period characterized by the expression of various proteins such as LMP1 and LMP2A/2B, and is further divided into Latency IIa and IIb. Latency IIa is a period of transition to Latency III, and is characterized by LMP1, LMP2A, and EBNA1 expression. In Latency IIa, the virus may provide infected cells the ability to avoid cytotoxic T lymphocyte attack through the mimicry of CD40 and B cell receptor signaling by LMP1 and LMP2A. In Latency IIb, which is characterized by the presence of EBNA2 expression and absence of LMP1 expression, infected cells prepare for transition to Latency III [11]. During Latency III, all the EBV gene products are expressed.

\section{EBV-Associated LPDs}

EBV-associated LPDs are associated with the three latency phases explained in the section "EBV biology". Latency I is associated with Burkitt lymphoma, Latency II with classic Hodgkin lymphoma (CHL) and extranodal NK/T-cell lymphoma, and Latency III with immunodeficiency-associated LPDs in patients in severely immunocompromised conditions such as HIV/AIDS [1,12].

Immunosuppression is considered to be one of the reasons underlying the emergence of EBV-associated LPDs. For example, Oyama et al. reported EBV-positive DLBCLs in elderly Japanese patients (age $>60$ years) who did not have predisposing immunodeficiencies [13]. They suggested that EBV-positive DLBCL could be associated with secondary immunosuppression due to aging. Many cases of iatrogenic immunodeficiency-associated LPDs that developed after methotrexate (MTX) treatment have been reported [1,14]. Histological analysis of MTX-associated LPDs often shows EBV-positive cells. Subsequently, EBVMCU was first described as a distinct clinicopathological entity in 2010 as one of the EBV-associated LPDs occurring in immunosuppressed patients [15].

\section{What Is EBVMCU?}

EBVMCUs are unifocal mucosal or cutaneous ulcers that are histologically characterized by proliferating EBV-positive atypical B cells. Because EBVMCUs are localized lesions, lymphadenopathy or involvement of any other organ is usually not noted. EBVMCUs have mainly been reported in the elderly, those with iatrogenic or primary immunodeficiencies [16-18], solid organ or bone marrow transplant recipients [19-22], and individuals with HIV / AIDS [23]. Lesions often occur because of local trauma, including tooth extraction [24]. In general, patients with EBVMCUs exhibit a good prognosis with spontaneous regression or complete remission after acquiring immunocompetence [1].

According to the World Health Organization disease classification, there are four categories of immunodeficiency-associated LPDs: LPDs associated with primary immune disorders, lymphomas associated with HIV infections, post-transplant LPDs, and other iatrogenic immunodeficiency-associated LPDs. EBVMCU does not belong to any of these four categories; it was first established as a new clinicopathologic entity by the World Health Organization in 2017 [24].

\section{Clinical Findings for EBVMCU}

EBVMCUs are characterized by shallow, sharply circumscribed mucosal or cutaneous ulcers that predominantly occur in oropharyngeal areas without associated systemic symptoms and lymphadenopathy. Of note, EBVMCUs often occur in patients with immunodeficiency. 
In the EBVMCU case reports and series in an English-language PubMed search for EBVMCU from 2010 to 2020, we found 186 cases and analyzed all of these cases [5,15-23,25-69]. The median patient age was 71 years (age range, $0.4-101$ years; Table 2) with the male:female ratio of $0.82: 1$. In the case reports in our search range, EBVMCUs had a slight female predominance. Most previous case reports and series noted that EBVMCU patients were more likely to have autoimmune diseases and be on immunosuppressants.

Table 2. Case reports of EBVMCU (2010-2020) [5,15-23,25-69].

\begin{tabular}{|c|c|c|c|c|}
\hline & Number of Cases (\%) & Mean Age (Years) & Age Range (Years) & Sex (Male, \%/Female, \%) \\
\hline \multicolumn{5}{|c|}{ Iatrogenic Immunodeficiency-Associated EBVMCU $(n=119)$} \\
\hline Oropharyngeal & $85(45.7)$ & 73 & $17-91$ & $32(37.6) / 53(62.4)$ \\
\hline Skin & $14(7.5)$ & 63 & $47-80$ & $3(21.4) / 11(78.6)$ \\
\hline Gastrointestinal & $20(10.8)$ & 67.5 & $26-81$ & $14(70.0) / 6(30.0)$ \\
\hline \multicolumn{5}{|c|}{ EBVMCU due to age-associated immunosenescence $(n=46)$} \\
\hline Oropharyngeal & $31(16.7)$ & 79 & $51-101$ & $17(54.8) / 14(45.2)$ \\
\hline Skin & $4(2.2)$ & 77 & $74-88$ & $3(75.0) / 1(25.0)$ \\
\hline Gastrointestinal & $11(5.9)$ & 72 & $42-84$ & $5(45.5) / 6(54.5)$ \\
\hline \multicolumn{5}{|c|}{ EBVMCU with post-solid organ or bone marrow transplant $(n=12)$} \\
\hline Oropharyngeal & $6(3.2)$ & 57.5 & $18-70$ & $4(66.7) / 2(33.3)$ \\
\hline Gastrointestinal & $6(3.2)$ & 57.5 & $32-70$ & $3(50.0) / 3(50.0)$ \\
\hline \multicolumn{5}{|c|}{ HIV / AIDS-Associated EBVMCU $(n=2)$} \\
\hline \multicolumn{5}{|c|}{2 cases (54-year-old male, 36-year-old female) ${ }^{23}$} \\
\hline \multicolumn{5}{|c|}{ Primary Immunodeficiency-Associated EBVMCU $(n=4)$} \\
\hline Gingiva & \multicolumn{4}{|c|}{ 45-year-old female with T-cell deficiency ${ }^{17}$} \\
\hline Esophagus & \multicolumn{4}{|c|}{ 61-year-old male with hypogammaglobunemia ${ }^{18}$} \\
\hline Nasopharyngeal & \multicolumn{4}{|c|}{ 16-year-old male with CHARGE syndrome ${ }^{16}$} \\
\hline Skin & \multicolumn{4}{|c|}{ 5-month-old boy with premature birth ${ }^{57}$} \\
\hline \multicolumn{5}{|c|}{ Chronic Antigenic Stimulation-Associated EBVMCU $(n=1)$} \\
\hline Sinus & \multicolumn{4}{|c|}{ 59-year-old female } \\
\hline & \multicolumn{4}{|c|}{ EBVMCU of Unclear Etiology $(n=2)$} \\
\hline Oropharyngeal & \multicolumn{4}{|c|}{2 cases (49-year-old female, 49 -year-old female) $[5,16]$} \\
\hline Total & 186 & 71 & $0.4-101$ & $84(45.2) / 102(54.8)$ \\
\hline
\end{tabular}

EBVMCU, Epstein-Barr virus-positive mucocutaneous ulcer; HIV/AIDS, human immunodeficiency virus/acquired immunodeficiency syndrome.

EBVMCUs may emerge when the virus overwhelms the host's immune response. Ulcer eruption may result from immune abnormalities caused by immunosuppression. For example, in patients who have immunosenescence, iatrogenic immunosuppression or primary immunodeficiencies [16-18], or HIV / AIDS [23] or have received solid organ or bone marrow transplants. In these immunosuppressed patients, local trauma, including tooth extraction, could lead to the development of EBVMCUs [24]. Patients exhibit sharply circumscribed mucosal or cutaneous ulcers, with $69.3 \%$ of the ulcers occurring in oropharyngeal lesions (Figure 1) [5,15-23,25-69]. EBVMCUs often develop in the oral cavity and pharynx (including the tonsils), which may be due to the release of EBV into saliva.

The levels of lymphoma prognosis-related laboratory markers, such as soluble interleukin 2 receptor (sIL-2R) and lactate dehydrogenase (LDH) [53], do not increase in patients with EBVMCU. These levels are relatively lower than those in patients with EBV-positive or EBV-negative DLBCL. In a retrospective study, the median $\mathrm{LDH}$ value was $212 \mathrm{U} / \mathrm{mL}$ (151-397 U/mL) in patients with EBVMCU and $265 \mathrm{U} / \mathrm{mL}(146-903 \mathrm{U} / \mathrm{mL})$ in patients with EBV-positive DLBCL. The median sIL-2R value was $652 \mathrm{U} / \mathrm{mL}(263-2786 \mathrm{U} / \mathrm{mL})$ in patients with EBVMCU and $4584 \mathrm{U} / \mathrm{mL}(460-18,600 \mathrm{U} / \mathrm{mL})$ in patients with EBV-positive DLBCL. In addition, serous sIL-2R levels aid in distinguishing between EBVMCU and systemic EBV-positive LPDs. 


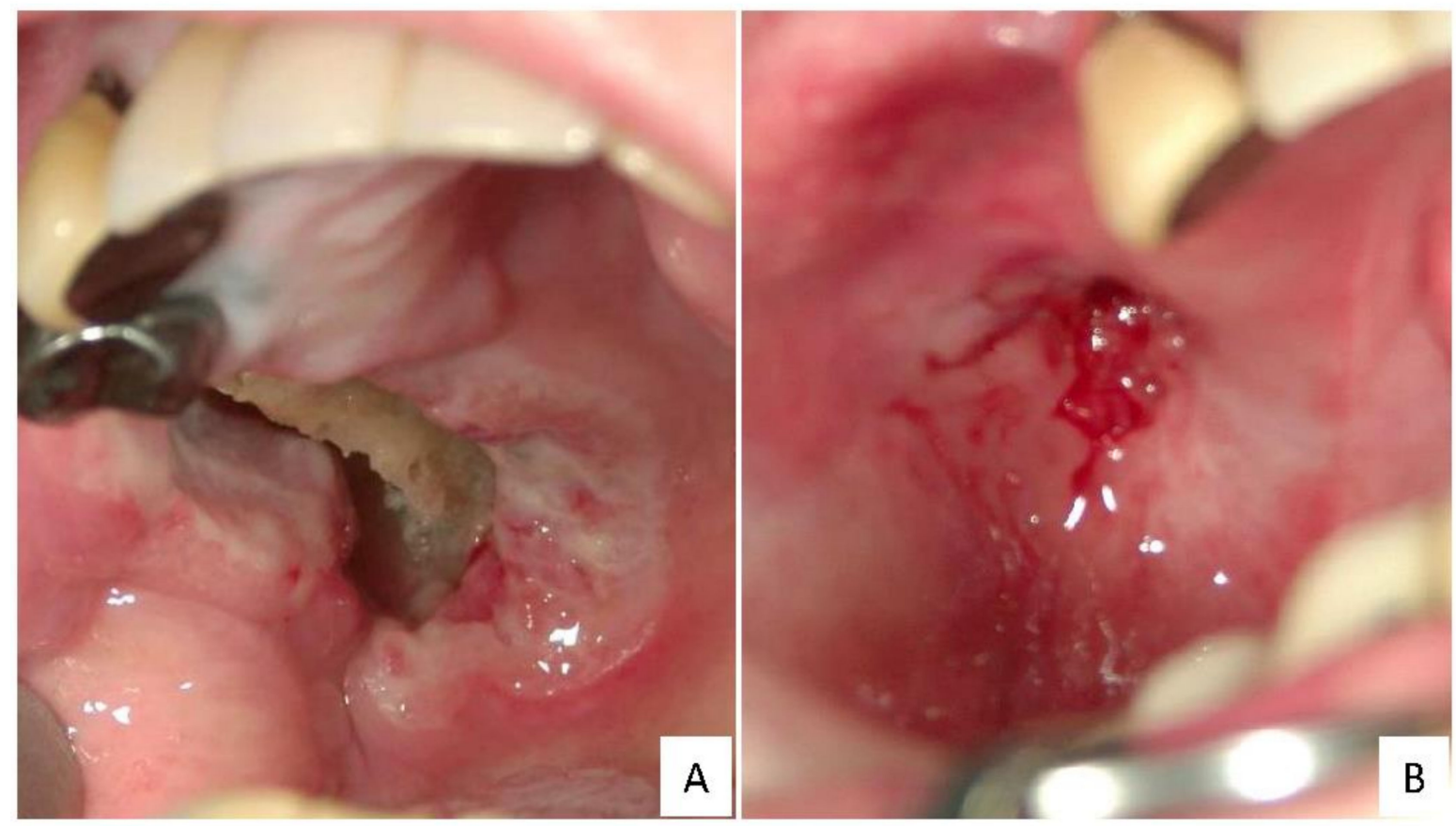

Figure 1. Representative macroscopic findings for EBVMCU in the gingival mucosa. The ulcer developed while the patient was on methotrexate (A). After the methotrexate dose was discontinued, the lesion spontaneously disappeared (B).

In 186 EBVMCU cases [5,15-23,25-69], during the follow-up periods (1-180 months), spontaneous improvement of the ulcers was noted in eight patients, and 126 patients had either complete or partial remission after discontinuation or dose reduction of immunosuppressants, chemotherapy, or radiotherapy. While eight patients experienced recurrence $[15,16,42,53]$, only four patients had progressive disease $[16,18,26,58]$. Table 3 summarizes the treatment and outcome of the 186 EBVMCU patients. In view of the frequent spontaneous recovery, patients with EBVMCU are considered to have a favorable prognosis.

Table 3. Treatment and clinical courses of 186 EBVMCU cases (2010-2020) [5,15-23,25-69].

\begin{tabular}{|c|c|c|c|c|c|c|}
\hline & SR/CR & PR & SD & PD & $\mathbf{R R}$ & NR \\
\hline \multicolumn{7}{|c|}{ Iatrogenic Immunodeficiency-Associated EBVMCU $(n=119)$} \\
\hline RIS $(n=73,61.3 \%)$ & 57 & 10 & - & 2 & - & 4 \\
\hline RIS, Rituximab $(n=5,4.2 \%)$ & 4 & - & - & - & 1 & - \\
\hline RIS, Chemotherapy $(n=6,5.0 \%)$ & 6 & - & - & - & - & - \\
\hline RIS, Resection $(n=2,1.7 \%)$ & 2 & - & - & - & - & - \\
\hline Chemotherapy $(n=5,4.2 \%)$ & 3 & - & - & 1 & - & 1 \\
\hline Antibody therapy $(n=1,0.8 \%)$ & 0 & - & - & - & - & 1 \\
\hline Resection $(n=8,6.7 \%)$ & 1 & - & - & - & - & 7 \\
\hline None $(n=8,6.7 \%)$ & 5 & - & - & 1 & 2 & - \\
\hline $\operatorname{NR}(n=11,9.2 \%)$ & 2 & - & - & - & - & 9 \\
\hline \multicolumn{7}{|c|}{ EBVMCU due to age-associated immunosenescence $(n=46)$} \\
\hline Rituximab $(n=1,2.2 \%)$ & 1 & - & - & - & - & - \\
\hline Chemotherapy $(n=13,28.3 \%)$ & 11 & - & - & - & - & 2 \\
\hline $\mathrm{RT}(n=4,8.7 \%)$ & 4 & - & - & - & - & - \\
\hline Chemotherapy, RT $(n=1,2.2 \%)$ & 1 & - & - & - & - & - \\
\hline $\begin{array}{l}\text { Chemotherapy, RT, and Resection } \\
\qquad(n=1,2.2 \%)\end{array}$ & 1 & - & - & - & - & - \\
\hline Resection $(n=6,13.0 \%)$ & 4 & - & - & - & - & 2 \\
\hline None $(n=12,26.1 \%)$ & 8 & - & 1 & - & 3 & - \\
\hline $\operatorname{NR}(n=8,17.4 \%)$ & - & - & - & - & - & 8 \\
\hline
\end{tabular}


Table 3. Cont.

\begin{tabular}{|c|c|c|c|c|c|c|}
\hline & SR/CR & PR & SD & PD & $\mathbf{R R}$ & NR \\
\hline \multicolumn{7}{|c|}{ EBVMCU with post-solid organ or bone marrow transplant $(n=12)$} \\
\hline RIS $(n=6,50.0 \%)$ & 6 & - & - & - & - & - \\
\hline RIS, Rituximab ( $n=3,25.0 \%)$ & 3 & - & - & - & - & - \\
\hline RIS, Resection $(n=1,8.3 \%)$ & 1 & - & - & - & - & - \\
\hline None $(n=1,8.3 \%)$ & 1 & - & - & - & - & - \\
\hline $\operatorname{NR}(n=1,8.3 \%)$ & - & - & - & - & - & 1 \\
\hline \multicolumn{7}{|c|}{ HIV / AIDS-Associated EBVMCU $(n=2)$} \\
\hline $\operatorname{NR}(n=2,100 \%)$ & - & - & - & - & - & 2 \\
\hline \multicolumn{7}{|c|}{ Primary Immunodeficiency-Associated EBVMCU $(n=4)$} \\
\hline Rituximab $(n=1,25.0 \%)$ & 1 & - & - & - & - & - \\
\hline $\begin{array}{c}\text { Rituximab, brentuximab, IVIG } \\
(n=1,25.0 \%)\end{array}$ & - & - & - & 1 & - & - \\
\hline $\begin{array}{c}\text { Chemotherapy and HSCT } \\
(n=1,25.0 \%)\end{array}$ & - & - & - & - & 1 & - \\
\hline Resection $(n=1,25.0 \%)$ & 1 & - & - & - & - & - \\
\hline \multicolumn{7}{|c|}{ Chronic Antigenic Stimulation-Associated EBVMCU $(n=1)$} \\
\hline $\mathrm{RT}(n=1,100.0 \%)$ & 1 & - & - & - & - & - \\
\hline \multicolumn{7}{|c|}{ EBVMCU of Unclear Etiology $(n=2)$} \\
\hline $\operatorname{RT}(n=1,50.0 \%)$ & - & - & - & - & 1 & - \\
\hline Rituximab, RT $(n=1,50.0 \%)$ & 1 & - & - & - & - & - \\
\hline Total & 125 & 10 & 1 & 5 & 8 & 37 \\
\hline
\end{tabular}

CR, complete remission; HSCT, hematopoietic stem cell transplant; IVIG, intravenous immunoglobulin; NR, not reported; PD, progressive disease; PR, partial remission; RIS, reduced or discontinued immunosuppressant; RR, relapsing remitting; RT, radiation; SD, stable disease; SR, spontaneous regression, -, no applicable case.

\section{Pathological Findings for EBVMCU}

EBVMCUs are characterized by localized mucosal or cutaneous ulcers with EBVpositive atypical lymphoid cells accompanied by dense polymorphic infiltration with various inflammatory cells such as plasma cells, histiocytes, and granulocytes. EBVpositive atypical cells range in size from small to large, and may resemble Hodgkin and Reed-Sternberg (HRS)-like cells. Angioinvasion by these cells is often seen in EBVMCUs. In most cases, EBV-positive cells are positive for CD20 and CD79a and exhibit characteristics of B lymphocytes. These cells are usually also positive for CD30, PAX5, OCT2, and MUM1, with variable expression of BOB1. CD15 is expressed in approximately $50 \%$ of cases $[1,24]$.

In some cases of EBVMCUs, the pathological findings are similar to those of DLBCL or CHL. A recent study classified EBVMCUs into four morphological subtypes on the basis of histological features [53].

\subsection{Polymorphous}

In this subtype of EBVMCU, various small-to-large atypical EBV-positive lymphoid cells, occasionally with a few HRS-like cells, are noted. Atypical lymphoid cells are found in dense clusters or are scattered (Figure 2). Fifty-nine percent of the cases in this study belonged to the polymorphous subtype [53].

\subsection{Large Cell-Rich}

In this subtype, dense proliferation of large and monomorphic atypical EBV-positive lymphoid cells, similar to that in DLBCL, is noted (Figure 3). Twenty-one percent of the cases in this study belonged to the large cell-rich subtype [53]. 


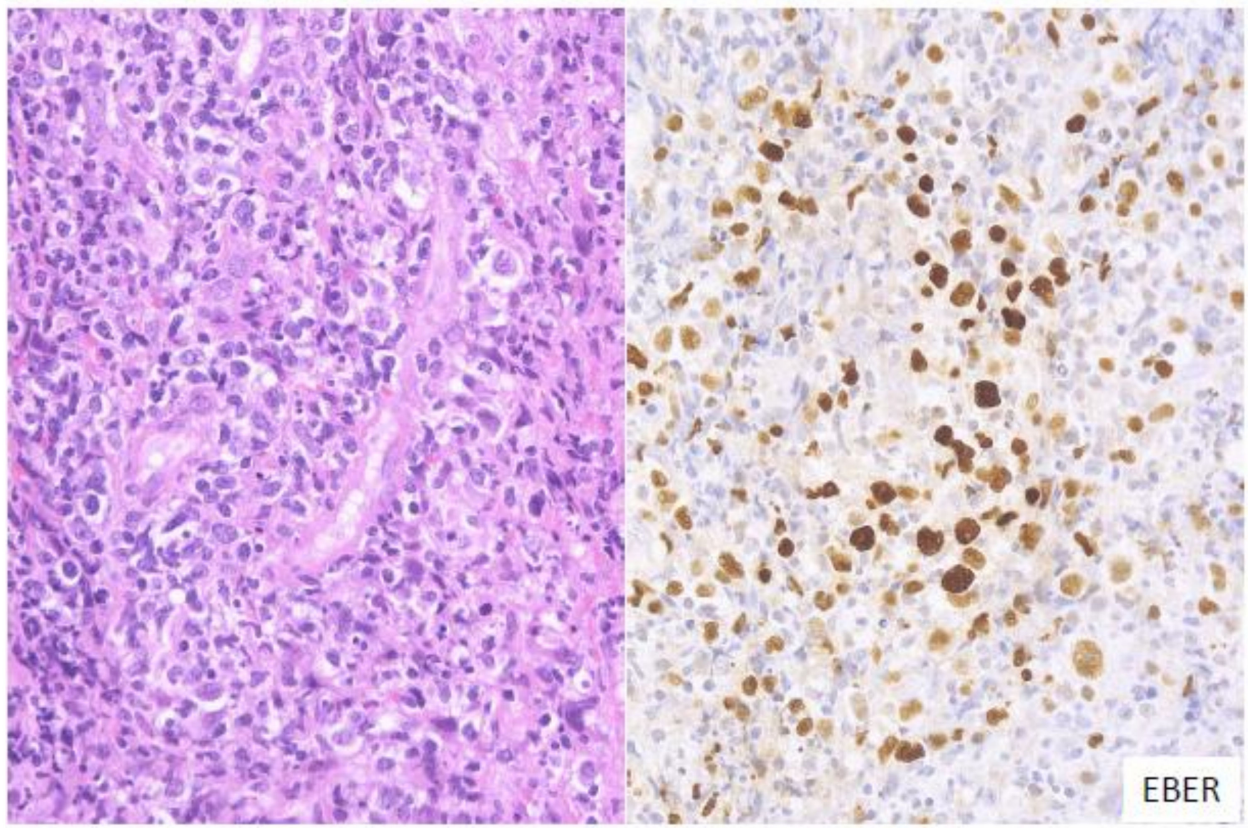

Figure 2. Pathologic findings for polymorphous EBVMCU. A tonsillar EBVMCU in a patient undergoing methotrexate treatment. Atypical lymphoid cells with polymorphous morphology and angioinvasion are seen, and are positive for EBV-encoded small RNA (EBER) (HE and EBER staining; magnification, $\times 400)$.

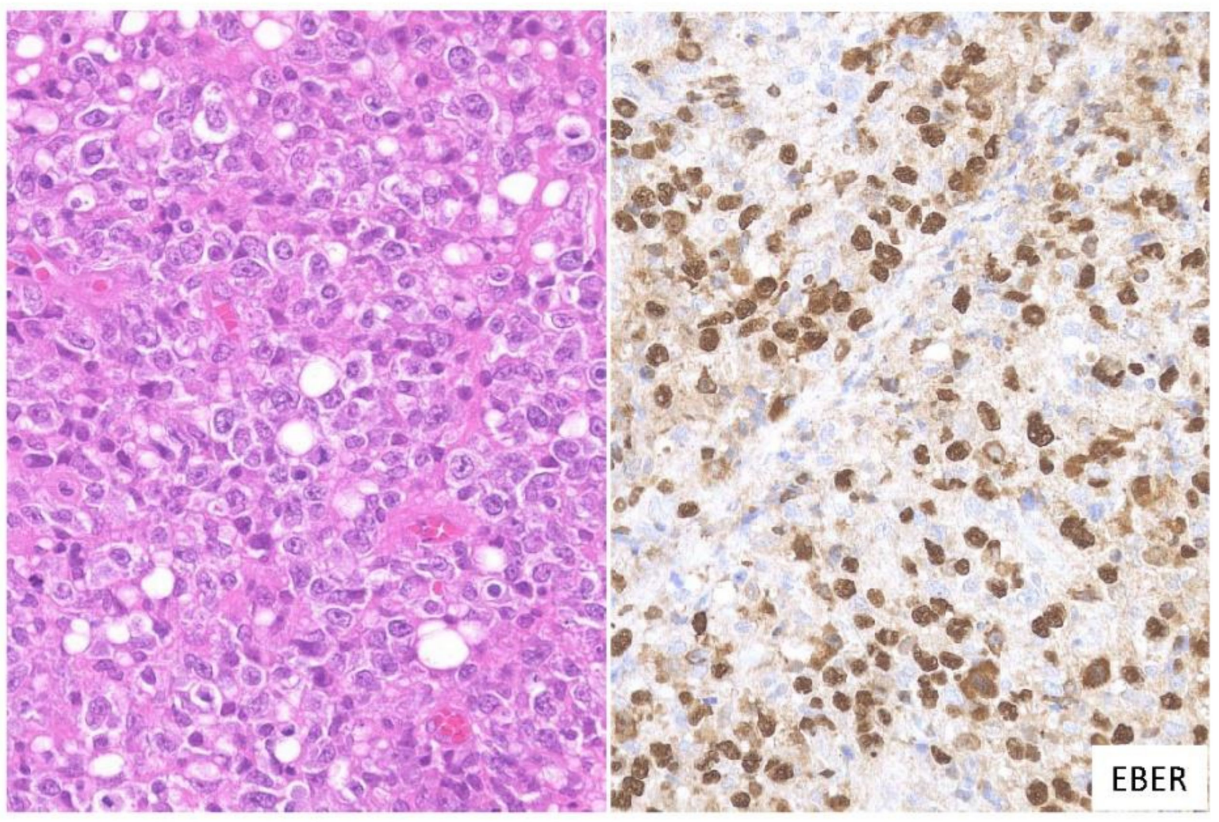

Figure 3. Pathologic findings for large cell-rich EBVMCU. An EBVMCU in the maxilla. The lesion shows monomorphic and dense proliferation of atypical large lymphoid cells resembling diffuse large B-cell lymphoma (DLBCL). In situ hybridization shows atypical cells positive for EBER (HE staining; magnification, $\times 400)$.

\subsection{CHL-Like}

In this subtype, many HRS-like EBV-positive cells and various-sized EBV-positive atypical lymphoid cells, sometimes with epithelioid granulomas or eosinophil infiltration, are noted. The HRS-like cells are positive for CD30, similar to the findings for CHL (Figure 4). Twelve percent of the EBVMCU cases were classified as CHL-like [53]. 


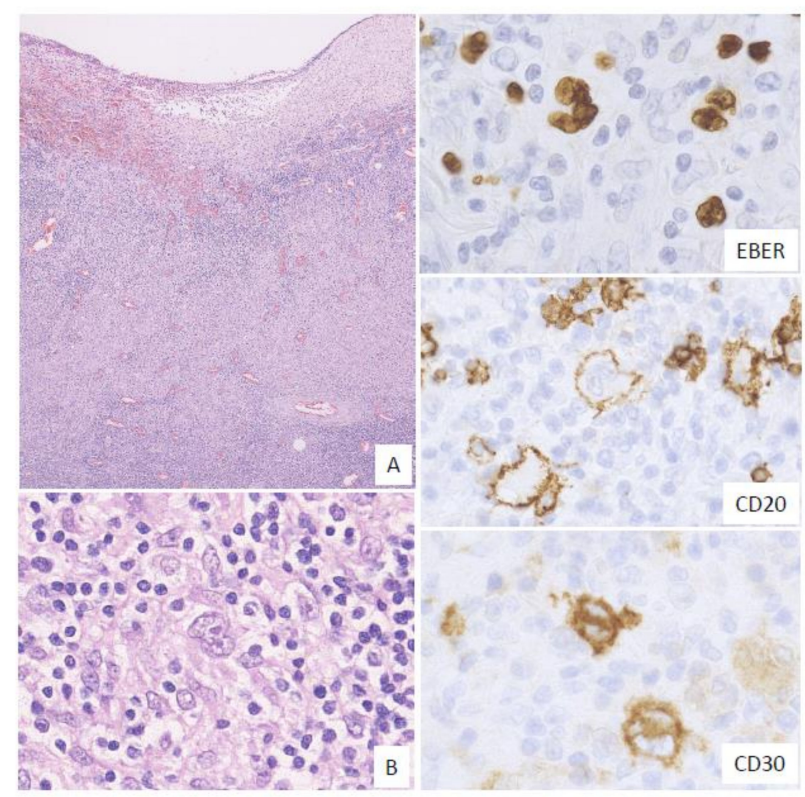

Figure 4. Pathologic findings for classic Hodgkin lymphoma (CHL)-like EBVMCU. A tonsillar EBVMCU in a patient undergoing methotrexate treatment. (A) Lymphoid cell infiltration with epithelioid granuloma is observed under the ulcer (magnification, $\times 40$ ). (B) This lesion contains many Hodgkin and Reed-Sternberg (HRS)-like cells (magnification, $\times 400$ ). The HRS-like cells and other polymorphous atypical lymphoid cells were positive for EBER; the HRS-like cells were also positive for CD20 and CD30 (EBER, CD20, and CD30: magnification, $\times 400)$.

\subsection{Mucosa-Associated Lymphoid Tissue (MALT) Lymphoma-Like}

In this subtype, small-to-medium-sized atypical lymphoid cells that show centrocyticlike features and/or plasmacytic features and proliferate in the expanded interfollicular zone are noted (Figure 5). In our previous study, 9\% of the EBVMCU cases belonged to this subtype [53].

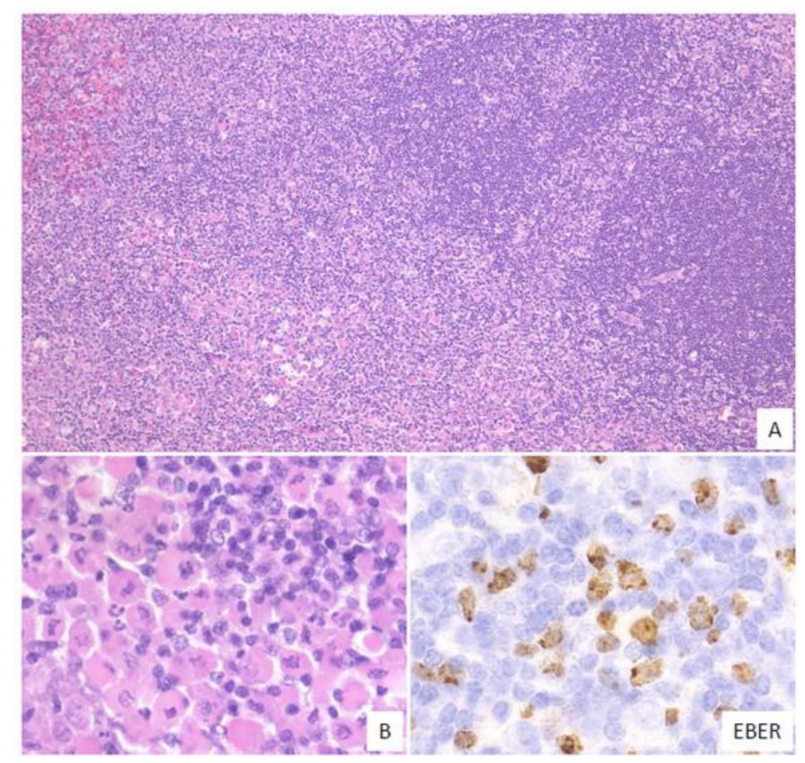

Figure 5. Pathologic findings for mucosa-associated lymphoid tissue (MALT) lymphoma-like EBVMCU. A lingual EBVMCU in a patient undergoing methotrexate treatment. (A) The atypical lymphoid cells show centrocytic-like features with plasmacytic differentiation and are proliferating in the expanded interfollicular zone (magnification, $\times 100$ ). (B) Atypical plasmacytic cells with Russell bodies are seen (magnification, $\times 400$ ). The atypical lymphoid cells are positive for EBER (magnification, $\times 400$ ). 
Another study reported an EBVMCU case that resembled plasmablastic lymphoma (PBL) [56]. Furthermore, some studies have reported good prognoses among patients diagnosed with HIV-negative PBL [70-74]. Thus, some PBLs, especially HIV-negative cases, may be part of the morphological subtype of EBVMCU. It is challenging to distinguish EBVMCUs from other LPDs, such as EBV-positive DLBCL, solely on the basis of pathological features.

\section{Genetic Findings for EBVMCU}

Genetic studies have been performed to characterize EBVMCUs, including the many reports on detection of clonality in EBVMCUs. In 2010, Dojcinov et al. was the first to report that $38 \%$ of the EBVMCUs studied exhibited immunoglobulin heavy chain (IGH) rearrangements [15]. Other studies reported that patients with EBVMCUs had a relatively lower frequency of clonal IGH rearrangements than patients with EBV-positive or EBVnegative DLBCLs $[53,75]$. In our previous study, clonal IGH rearrangements were detected in $44 \%$ of the EBVMCUs, $32 \%$ of EBV-positive DLBCLs, and 58\% of EBV-negative DLBCLs; these differences were not statistically significant. Thus, IGH rearrangements are not useful for distinguishing between EBVMCU and DLBCL.

Clonal T cell receptor (TCR) rearrangements tend to occur more frequently in EBVMCUs than in EBV-positive and EBV-negative DLBCLs [53]. In our previous study, clonal TCR rearrangements were found in $32 \%$ of EBVMCUs, $10 \%$ of EBV-positive DLBCLs, and $15 \%$ of EBV-negative DLBCLs. Another previous study supported this T-cell clonality; in that study, serum CD8+ T cells increased after MTX reduction in patients who had MTX-LPD and achieved complete remission only due to MTX reduction [76]. Another study showed that B-cell post-transplant LPD was associated with clonal expansion of CD8+ T cells [77]. Thus, we considered that EBVMCU might also be associated with T-cell clonal expansion due to reduced immune surveillance.

Some studies suggested that TCR gene rearrangements could lead to a limited T cell repertoire, which triggers EBV infections in the elderly and in immunocompromised patients $[77,78]$. The leading players in T cell-mediated immune responses are CD8+ mature memory $\mathrm{T}$ cells. In the patient population, $\mathrm{T}$ cell epitope recognition might be disabled due to dysfunction of CD8+ mature memory T cells and the CD8+ cells could miss the EBV epitope [78]. This T cell dysfunction might lead to an increase in the number of EBV-positive cells.

Recently, programmed death-ligand 1 (PD-L1) has received attention for its involvement in immune evasion systems. PD-L1 expression in cancer cells suppresses T cell activation, allowing cancer cells to escape the immune surveillance mechanism. Previous studies have shown the presence of PD-L1 expression in most cases of EBV-positive DLBCL [79-81]; however, PD-L1 expression was absent in almost all cases of EBVMCUs [64,82]. These results suggest that, in contrast to EBV-positive DLBCLs, EBVMCUs may not possess an immune evasion mechanism.

\section{Conclusions}

EBVMCU is a new disease concept proposed in the last decade. It differs from EBVassociated lymphomas such as EBV-positive DLBCL in that it causes localized lesions and has a good prognosis, although it is challenging to distinguish EBVMCUs from other EBV-positive LPDs solely on the basis of pathological features. Systemic chemotherapy is often unnecessary in patients with EBVMCU. Recognizing the differences between the disease process of EBVMCU and of other associated entities is important for enabling provision of disease-specific treatment and follow-up plans by clinicians and pathologists. Several aspects of the immune mechanism of EBVMCU remain unclear; in particular, the role of $\mathrm{T}$ cell clonality and immune checkpoints has not yet been determined. The clinical and pathological features of EBVMCU have been investigated in some studies to date. Therefore, analysis of more EBVMCU cases, with a focus from the side of genetic or molecular aspects, is required in order to elucidate the immune mechanism. 
Author Contributions: T.I. and Y.S. conceived the idea, T.I., Y.G., Y.N., M.F.N., T.Y. and Y.S. wrote and evaluated the manuscript. All authors have read and agreed to the published version of the manuscript.

Funding: This work was partially supported by the Grant-in-Aid for Young Scientists [JSPS KAKENHI grant number 19K16586] and Scientific Research [C] [JSPS KAKENHI Grant Number JP 20K07407], from the Japan Society for the Promotion of Science.

Institutional Review Board Statement: Not applicable.

Informed Consent Statement: Not applicable.

Data Availability Statement: No new data were created or analyzed in this study.

Conflicts of Interest: The authors declare no conflict of interest.

\section{References}

1. Ikeda, T.; Gion, Y.; Yoshino, T.; Sato, Y. A review of EBV-positive mucocutaneous ulcers focusing on clinical and pathological aspects. J. Clin. Exp. Hematop. 2019, 59, 64-71. [CrossRef]

2. Liebowitz, D. Epstein-Barr Virus and a Cellular Signaling Pathway in Lymphomas from Immunosuppressed Patients. N. Engl. J. Med. 1998, 338, 1413-1421. [CrossRef]

3. Komano, J.; Maruo, S.; Kurozumi, K.; Oda, T.; Takada, K. Oncogenic Role of Epstein-Barr Virus-Encoded RNAs in Burkitt's Lymphoma Cell Line Akata. J. Virol. 1999, 73, 9827-9831. [CrossRef]

4. Komano, J.; Maruo, S.; Takada, K. Epstein-Barr Virus Contributes to the Malignant Phenotype and to Apoptosis Resistance in Burkitt's Lymphoma Cell Line Akata. J. Virol. 1998, 72, 9150-9156. [CrossRef]

5. Roberts, T.K.; Chen, X.; Liao, J.J. Diagnostic and therapeutic challenges of EBV-positive mucocutaneous ulcer: A case report and systematic review of the literature. Exp. Hematol. Oncol. 2016, 5, 1-14. [CrossRef]

6. Kutok, J.L.; Wang, F. Spectrum of Epstein-Barr Virus-Associated Diseases. Annu. Rev. Pathol. 2006, 1, 375-404. [CrossRef]

7. Fernandez, A.F.; Rosales, C.; Lopez-Nieva, P.; Graña, O.; Ballestar, E.; Ropero, S.; Espada, J.; Melo, S.A.; Lujambio, A.; Fraga, M.F.; et al. The dynamic DNA methylomes of double-stranded DNA viruses associated with human cancer. Genome Res. 2009, 19, 438-451. [CrossRef]

8. Rickinson, A.B. Co-infections, inflammation and oncogenesis: Future directions for EBV research. In Seminars in Cancer Biology; Academic Press: Cambridge, MA, USA, 2014; pp. 99-115.

9. Odumade, O.A.; Hogquist, K.A.; Balfour, H.H., Jr. Progress and Problems in Understanding and Managing Primary Epstein-Barr Virus Infections. Clin. Microbiol. Rev. 2011, 24, 193-209. [CrossRef]

10. Imai, K.; Ogata, Y. How Does Epstein-Barr Virus Contribute to Chronic Periodontitis? Int. J. Mol. Sci. 2020, 21, 1940. [CrossRef]

11. Price, A.M.; Luftig, M.A. To Be or Not IIb: A Multi-Step Process for Epstein-Barr Virus Latency Establishment and Consequences for B Cell Tumorigenesis. PLoS Pathog. 2015, 11, e1004656. [CrossRef]

12. Navari, M.; Etebari, M.; Ibrahimi, M.; Leoncini, L.; Piccaluga, P.P. Pathobiologic Roles of Epstein-Barr Virus-Encoded MicroRNAs in Human Lymphomas. Int. J. Mol. Sci. 2018, 19, 1168. [CrossRef]

13. Oyama, T.; Yamamoto, K.; Asano, N.; Oshiro, A.; Suzuki, R.; Kagami, Y.; Morishima, Y.; Takeuchi, K.; Izumo, T.; Mori, S.; et al. Age-related EBV-associated B-cell lymphoproliferative disorders constitute a distinct clinicopathologic group: A study of 96 patients. Clin. Cancer Res. 2007, 13, 5124-5132. [CrossRef]

14. Gion, Y.; Iwaki, N.; Takata, K.; Takeuchi, M.; Nishida, K.; Orita, Y.; Tachibana, T.; Yoshino, T.; Sato, Y. Clinicopathological analysis of methotrexate-associated lymphoproliferative disorders: Comparison of diffuse large B-cell lymphoma and classical Hodgkin lymphoma types. Cancer Sci. 2017, 108, 1271-1280. [CrossRef]

15. Dojcinov, S.D.; Venkataraman, G.; Raffeld, M.; Pittaluga, S.; Jaffe, E.S. EBV Positive Mucocutaneous Ulcer-A Study of 26 Cases Associated with Various Sources of Immunosuppression. Am. J. Surg. Pathol. 2010, 34, 405-417. [CrossRef]

16. Natkunam, Y.; Goodlad, J.R.; Chadburn, A.; Jong, D.; Gratzinger, D.; Chan, J.K.C.; Said, J.; Jaffe, E.S. EBV-Positive B-Cell Proliferations of Varied Malignant Potential. Am. J. Clin. Pathol. 2017, 147, 129-152. [CrossRef]

17. Au, W.Y.; Loong, F.; Wan, T.S.; Tong, A.C. Multi-focal EBV-mucocutaneous ulcer heralding late-onset T-cell immunodeficiency in a women with lupus erythematosus. Int. J. Hematol. 2011, 94, 501-502. [CrossRef]

18. Kleinman, S.; Jhaveri, D.; Caimi, P.; Cameron, R.; Lemonovich, T.; Meyerson, H.; Hostoffer, R.; Tcheurekdjian, H. A rare presentation of EBV+ mucocutaneous ulcer that led to a diagnosis of hypogammaglobulinemia. J. Allergy Clin. Immunol. Pract. 2014, 2, 810-812. [CrossRef]

19. Hart, M.; Thakral, B.; Yohe, S.; Balfour, H.H., Jr.; Singh, C.; Spears, M.; McKenna, R.W. EBV-positive Mucocutaneous Ulcer in Organ Transplant Recipients: A Localized Indolent Posttransplant Lymphoproliferative Disorder. Am. J. Surg. Pathol. 2014, 38, 1522-1529. [CrossRef]

20. Gali, V.; Bleeker, J.S.; Lynch, D. Epstein-Barr Virus Positive Mucocutaneous Ulcer: A Case Report. S. Dak. Med. 2018 , 71, $252-255$. 
21. Satou, A.; Kohno, A.; Fukuyama, R.; Elsayed, A.A.; Nakamura, S. Epstein-Barr virus-positive mucocutaneous ulcer arising in a post-hematopoietic cell transplant patient followed by polymorphic posttransplant lymphoproliferative disorder and cytomegalovirus colitis. Hum. Pathol. 2017, 59, 147-151. [CrossRef]

22. Nelson, A.A.; Harrington, A.M.; Kroft, S.; Dahar, M.A.; Hamadani, M.; Dhakal, B. Presentation and management of post-allogeneic transplantation EBV-positive mucocutaneous ulcer. Bone Marrow Transplant. 2016, 51, 300-302. [CrossRef] [PubMed]

23. Bunn, B.; Heerden, W.V. EBV-positive mucocutaneous ulcer of the oral cavity associated with HIV/AIDS. Oral Surg. Oral Med. Oral Pathol. Oral Radiol. 2015, 120, 725-732. [CrossRef] [PubMed]

24. Gaulard, P.; Swerdlow, S.H.; Harris, N.L.; Sundstrom, C.; Jaffe, E.S. EBV-positive mucocutaneous ulcer. In WHO Classification of Tumours of Haematopoietic and Lymphoid Tissues, 4th ed.; Swerdlow, S.H., Campo, E., Harris, N.L., Eds.; International Agency for Research on Cancer: Lyon, France, 2016; pp. 307-308.

25. Juan, A.; Lobaton, T.; Tapia, G.; Manosa, M.; Cabre, E.; Domenech, E. Epstein-Barr virus-positive mucocutaneous ulcer in Crohn's disease. A condition to consider in immunosuppressed IBD patients. Dig. Liver Dis. 2017, 49, 934-937. [CrossRef]

26. Moran, N.R.; Webster, B.; Lee, K.M.; Trotman, J.; Kwan, Y.-L.; Napoli, J.; Leong, R.W. Epstein Barr virus-positive mucocutaneous ulcer of the colon associated Hodgkin lymphoma in Crohn's disease. World J. Gastroenterol. 2015, 21, 6072-6076. [CrossRef]

27. Napoli, A.D.; Giubettini, M.; Duranti, E.; Ferrari, A.; Guglielmi, C.; Uccini, S.; Ruco, L. Iatrogenic EBV-positive lymphoproliferative disorder with features of EBV+ mucocutaneous ulcer: Evidence for concomitant TCR $\gamma /$ IGH rearrangements in the Hodgkin-like neoplastic cells. Virchows Arch. 2011, 458, 631-636. [CrossRef]

28. Ohata, Y.; Tatsuzawa, A.; Ohyama, Y.; Ichikawa, A.; Mochizuki, Y.; Ishibashi, S.; Itakura, Y.; Sakurai, U.; Sakamoto, K.; Ikeda, T.; et al. A distinctive subgroup of oral EBV+ B-cell neoplasm with polymorphous features is potentially identical to EBV+ mucocutaneous ulcer. Hum. Pathol. 2017, 69, 129-139. [CrossRef]

29. Yamakawa, N.; Fujimoto, M.; Kawabata, D.; Terao, C.; Nishikori, M.; Nakashima, R.; Imura, Y.; Yukawa, N.; Yoshifuji, H.; Ohmura, K.; et al. A clinical, pathological, and genetic characterization of methotrexate associate lymphoproliferative disorders. J. Rheum. 2014, 41, 293-299. [CrossRef]

30. Hashizume, H.; Uchiyama, I.; Kawamura, T.; Suda, T.; Takigawa, M.; Tokura, Y. Epstein-Barr virus-positive mucocutaneous ulcers as a manifestation of methotrexate-associated B-cell lymphoproliferative disorders. Acta Derm. Venereol. 2012, 92, 27607. [CrossRef]

31. Sadasivam, N.; Johnson, R.J.; Owen, R.G. Resolution of methotrexate-induced Epstein-Barr virus-associated mucocutaneous ulcer. Br. J. Haemotol. 2014, 165, 584. [CrossRef]

32. Attard, A.A.; Praveen, P.; Dunn, P.J.S.; James, G.J. Epstein-Barr virus-positive mucocutaneous ulcer of the oral cavity: The importance of having a detailed clinical history to reach a correct diagnosis. Oral Surg. Oral Med. Oral Pathol. Oral Radiol. 2012, 114, e37-e39. [CrossRef]

33. Matnani, R.; Peker, D. Azathioprine induced Epstein-Barr virus-positive mucocutaneous ulcer arising in perianal fistula and abscess associated with Crohn's disease. J. Crohns Colitis 2014, 8, 1747-1748. [CrossRef] [PubMed]

34. McGinness, J.L.; Spicknall, K.E.; Mutasim, D.F. Azathioprine-induced EBV-positive mucocutaneous ulcer. J. Cutan. Pathol. 2012, 39, 377-381. [CrossRef] [PubMed]

35. Kanemitsu, M.; John, D.; Lim, A.; Jaffe, E.S.; Aoki, J. Clonal Epstein-Barr viruspositive mucocutaneous ulcer mimicking a mature B-cell lymphoma in a patient with mycophenolate-induced immunosuppression. Leuk. Lymphoma. 2015, 56, 1908-1910. [CrossRef] [PubMed]

36. Sadiku, S.; Kurshumliu, F.; Krasniqi, X.; Brovina, A.; Kryeziu, E.; Rrudhani, I.; Meqa, K.; Gashi-Luci, L.; Merz, H. Age-related Epstein-Barr virus-positive cutaneous ulcer arising after a self-limited subcutaneous abscess: A case report. J. Med. Case. Rep. 2012, 6, 288-292. [CrossRef] [PubMed]

37. Magalhaes, M.; Ghorab, Z.; Morneault, J.; Akinfolarin, J.; Bradley, G. Age-related Epstein-Barr virus-positive mucocutaneous ulcer: A case report. Clin. Case. Rep. 2015, 3, 531-534. [CrossRef]

38. Soni, S.; Mercer, R.; Pattani, K.; Magill, J. Epstein-Barr virus positive mucocutaneous ulcer: A rare lesion presenting as a large lower lip mass. In Poster Presentation from the University of Central Florida College of Medicine; University of Central Florida: Orlando, FL, USA, 2014.

39. Hujoel, I.A.; Rubio-Tapia, A.; Dao, L.N.; Porrata, L.F.; Kane, S.V. Epstein-Barr virus-positive mucocutaneous ulcer in an immunosuppressed patient. ACG Case Rep. J. 2018, 5, 5-7. [CrossRef]

40. McCormack, C.; Huang, Q. EBV+ mucocutaneous ulcer: A new entity of WHO 2017. Blood 2018, 131, 1993. [CrossRef]

41. Ravi, P.Y.; Sigamani, E.; Jeelani, Y.; Manipadam, M.T. Methotrexate-associated Epstein-Barr virus mucocutaneous ulcer: A case report and review of literature. Indian J. Pathol. Microbiol. 2018, 61, 255-257.

42. Daroontum, T.; Kohno, K.; Eladl, A.E.; Satou, A.; Sakakibara, A.; Matsukage, S.; Yakushiji, N.; Ya-In, C.; Nakamura, S.; Asano, N.; et al. Comparison of Epstein-Barr virus-positive mucocutaneous ulcer associated with treated lymphoma or methotrexate in Japan. Histopathology 2018, 72, 1115-1127. [CrossRef]

43. Osman, M.; Salihi, M.A.; Sitta, E.A.; Hadidi, S.A. A rare case of Epstein-Barr virus mucocutaneous ulcer of the colon. BMJ Case Rep. 2017, 2017, bcr-2017. [CrossRef]

44. Maffione, A.M.; Rampin, L.; Paolini, R.; Rodella, E.; Lisato, L.C.; Ballotta, M.R.; Pavanato, G.; Montesi, G.; Colletti, P.; Rubello, D. Epstein-Barr Virus-Positive Mucocutaneous Ulcer Mimicking Rectal Carcinoma at 18F-FDG PET/CT. Clin. Nucl. Med. 2017, 42, 645-646. [CrossRef] [PubMed] 
45. Aldridge, T.; Paraneetharan; Brennan, P.A.; Ilankovan, V. Epstein-Barr-virus-related mucocutaneous ulceration that mimics oral squamous cell carcinoma: The importance of recognising this new condition. Br. J. Oral Maxillofac Surg. 2017, 55, 418-419. [CrossRef] [PubMed]

46. Chen, B.J.; Fang, C.-L.; Chuang, S.S. Epstein-Barr virus-positive mucocutaneous ulcer. Kaohsiung J. Med. Sci. 2017,33, 50-51. [CrossRef] [PubMed]

47. Vatsayan, A.; Gupta, A.; Ahuja, S.; Eglar, R.; Beck, R.C.; Matloub, Y. Epstein-Barr Virus-associated Mucocutaneous Ulcer in a Patient With T-Cell Acute Lymphoblastic leukemia: Importance of Accurate Diagnosis and Conservative Management. J. Pediatr. Hematol. Oncol. 2017, 39, e338-e341. [CrossRef]

48. Au, J.K.; Said, J.W.; Sepahdari, A.R.; John, M.A.S. Head and Neck Epstein-Barr Virus Mucocutaneous Ulcer: Case Report and Literature Review. Laryngoscope 2016, 126, 2500-2504. [CrossRef]

49. Nakauyaca, A.; Kalro, A.; Donaldson, E.; Patel, H. Fatal outcome of an Epstein-Barr virus positive mucocutaneous ulcer secondary to methotrexate. Intern. Med. J. 2016, 46, 1226-1228. [CrossRef]

50. Sinit, R.B.; Horan, K.L.; Dorer, R.K.; Aboulafia, D.M. Epstein-Barr Virus-Positive Mucocutaneous Ulcer: Case Report and Review of the First 100 Published Cases. Clin. Lymphoma Myeloma Leuk. 2018, 19, e81-e92. [CrossRef]

51. Pina-Oviedo, S.; Miranda, R.N.; Medeiros, L.J. Cancer therapy-associated lymphoproliferative disorders: An under-recognized type of immunodeficiency-associated lymphoproliferative disorder. Am. J. Surg. Pathol. 2018, 42, 116-129. [CrossRef]

52. Mendes, L.S.T.; McCaul, J.; Wotherspoon, A.; Attygalle, A.D. Epstein-Barr virus-positive mucocutaneous ulcer with a background of Crohn's disease and Waldenström macroglobulinaemia: A case report highlighting diagnostic pitfalls. Histopathology 2018, 72, 874-877. [CrossRef]

53. Ikeda, T.; Gion, Y.; Sakamoto, M.; Tachibana, T.; Nishikori, A.; Nishimura, M.F.; Yoshino, T.; Sato, Y. Clinicopathological analysis of 34 Japanese patients with EBV-positive mucocutaneous ulcer. Mod. Pathol. 2020, 33, 2437-2448. [CrossRef]

54. Gabsi, A.; Zenzri, Y.; Sahraoui, G.; Brahim, I.B.; Cherif, M.; Yahyaoui, Y.; Charaiet, N.; Mrad, K.; Chedly, C.; Maamer, A.B.; et al. Gastric EBV-positive mucocutaneous ulcer: A rare pathological entity. Clin. Case Rep. 2020, 8, 1130-1133. [CrossRef] [PubMed]

55. Ritter, C.G.; Cruz, C.D.; Zamboni, S.; Busato, V.B.; Silveira, R.G.; Provenzi, V.O.; Bredemeier, M. EBV-positive mucocutaneous ulcer in a patient with systemic lupus erythematosus. Rheumatology 2020, 59, 916. [CrossRef] [PubMed]

56. Chen, B.J.; Chiang, W.F.; Chen, T.S.; Kao, H.J.; Chuang, S.S. EBV positive mucocutaneous ulcer with plasmacytic/plasmablastic differentiation and MYC rearrangement: A diagnostic challenge and a mimic of plasmablastic lymphoma. Pathology 2019, 51, 648-650. [CrossRef] [PubMed]

57. Coelho, K.M.P.A.; Bublitz, G.S.; Franca, P.H.C.; Stall, J.; Hanauer, A.D.; Sangueza, J.M. Epstein-Barr Virus-Positive Mucocutaneous Ulcer in a Pediatric Patient-Case Report. Am. J. Dermatopathol. 2020, 42, e49-e52. [CrossRef] [PubMed]

58. Hamanaka, S.; Nakagawa, T.; Ota, S.; Iida, M.; Ohta, Y.; Isshiki, Y.; Kasamatsu, S.; Ishigami, H.; Taida, T.; Okimoto, K.; et al. Immunomodulator-associated Epstein-Barr virus-positive mucocutaneous ulcer in a patient with refractory Crohn's disease. Clin. J. Gastroenterol. 2019, 12, 330-335. [CrossRef] [PubMed]

59. Karube, K.; Takatori, M.; Kohno, K.; Tomoyose, T.; Ohshiro, K.; Nakazato, I. Co-occurrence of EBV-positive classic Hodgkin lymphoma and B-cell lymphomas of different clonal origins: A case report and literature review. Pathol. Int. 2020, 70, 893-898. [CrossRef]

60. Zanelli, M.; Zizzo, M.; Foroni, M.; Marco, L.D.; Martino, G.; Ascani, S. EBV-positive mucocutaneous ulcer within colonic diverticulitis mimicking diffuse large B cell lymphoma. Ann. Hematol. 2019, 98, 1795-1797. [CrossRef]

61. Moriya, K.; Kikuti, Y.Y.; Carreras, J.; Kondo, Y.; Shiraiwa, S.; Nakamura, N. Methotrexate-associated lymphoproliferative disorder demonstrating composite lymphoma of EBV-negative diffuse large B-cell lymphoma and EBV-positive mucocutaneous ulcer. $J$. Clin. Exp. Hematop. 2020, 60, 11-16. [CrossRef]

62. Lacet, D.F.R.; Oliveira, C.C. Challenging diagnoses in oral ulcers with large atypical CD30+ cells: EBV-positive mucocutaneous ulcer differentials. J. Clin. Exp. Hematop. 2020, 60, 21-23. [CrossRef]

63. Miyagi, S.; Ishikawa, E.; Nakamura, M.; Shimada, K.; Yamamura, T.; Furukawa, K.; Tanaka, T.; Mabuchi, S.; Tsuyuki, Y.; Kohno, K.; et al. Reappraisal of Primary Epstein-Barr Virus [EBV]-positive Diffuse Large B-Cell Lymphoma of the Gastrointestinal Tract: Immunosuppressed and nonimmunosuppressed stage I and II-IV patients. Am. J. Surg. Pathol. 2020, 44, 1173-1183. [CrossRef]

64. Satou, A.; Banno, S.; Hanamura, I.; Takahashi, E.; Takahara, T.; Nobata, H.; Katsuno, T.; Takami, A.; Ito, Y.; Ueda, R.; et al. EBV-positive mucocutaneous ulcer arising in rheumatoid arthritis patients treated with methotrexate: Single center series of nine cases. Pathol. Int. 2019, 69, 21-28. [CrossRef] [PubMed]

65. Daroontum, T.; Kohno, K.; Inaguma, Y.; Okamoto, A.; Okamoto, M.; Kimura, Y.; Nagahama, M.; Sakakibara, A.; Satou, A.; Nakamura, S. Epstein-Barr virus [EBV]-positive diffuse large B-cell lymphoma arising in patient with a history of EBV-positive mucocutaneous ulcer and EBV-positive nodal polymorphous B-lymphoproliferative disorder. Pathol. Int. 2019, 69, 37-41. [CrossRef] [PubMed]

66. Tsutsumi, M.; Yoshimura, T.; Tatsumi, N.; Nakaya, Y.; Fuseya, H.; Horiuchi, M.; Yoshida, M.; Hayashi, Y.; Nakao, T.; Inoue, T.; et al. Aggressive Tongue Root Epstein-Barr Virus-Positive Mucocutaneous Ulcer Treated With Rituximab Alone. Clinical Lymphoma. Myeloma Leuk. 2020, 20, e291-e294. [CrossRef] [PubMed]

67. Goel, D.; Singh, M. EBV positive mucocutaneous ulcer of palate: A mimicker of malignancy. Indian J. Pathol. Microbiol. 2019, 62, 632-634. [CrossRef] [PubMed] 
68. Pugh, M.R.; Leopold, G.D.; Morgan, M.; Christian, A.D.; Hewett, R.; Durai, D.; Wagstaff, J.; Harris, D.; Dojcinov, S.D. Epstein-Barr Virus-Positive Mucocutaneous Ulcers Complicate Colitis Caused by Immune Checkpoint Regulator Therapy and Associate With Colon Perforation. Clin. Gastroenterol. Hepatol. 2020, 18, 1785-1795. [CrossRef]

69. Morita, N.; Okuse, C.; Suetani, K.; Nakano, H.; Hiraishi, T.; Ishigooka, S.; Mori, S.; Shimamura, T.; Asakura, T.; Koike, J.; et al. A rare case of Epstein-Barr virus-positive mucocutaneous ulcer that developed into an intestinal obstruction: A case report. BMC Gastroenterol. 2020, 20, 9. [CrossRef]

70. Yamada, T.; Kitamura, N.; Sasabe, E.; Yamamoto, T. Plasmablastic lymphoma of the upper gingiva in an HIV-negative elderly patient. Oral Maxillofac. Surg. Cases 2015, 1, 19-24. [CrossRef]

71. Igawa, T.; Sato, Y.; Kawai, H.; Kondo, E.; Takeuchi, M.; Miyata-Takata, T.; Takata, K.; Yoshino, T. Spontaneous regression of plasmablastic lymphoma in an elderly human immunodeficiency virus [HIV]-negative patient. Diagn. Pathol. 2015, 10, 183. [CrossRef]

72. Yordanova, K.; Stilgenbauer, S.; Bohle, R.M.; Lesan, V.; Thurner, L.; Kaddu-Mulindwa, D.; Bittenbring, J.T.; Scharberger, M.; Aßmann, G.; Bewarder, M. Spontaneous regression of a plasmablastic lymphoma with MYC rearrangement. Br. J. Haematol. 2019, 186, e163-e225. [CrossRef]

73. Sasaki, J.; Kamamoto, M.; Takagi, Y.; Hanada, H.; Kurokawa, Y.; Fujiwara, S. A case of EBV-positive plasmablastic lymphoma in the mandibular gingiva of an elderly HIV-negative patient. Jpn. J. Oral Maxillofac. Surg. 2019, 65, 306-311. [CrossRef]

74. Liu, F.; Asano, N.; Tatematsu, A.; Oyama, T.; Kitamura, K.; Suzuki, K.; Yamamoto, K.; Sakamoto, N.; Taniwaki, M.; Kinoshita, T.; et al. Plasmablastic lymphoma of the elderly: A clinicopathological comparison with age-related Epstein-Barr virus-associated B cell lymphoproliferative disorder. Histopathology 2012, 61, 1183-1197. [PubMed]

75. Dojcinov, S.D.; Venkataraman, G.; Pittaluga, S.; Wlodarska, I.; Schrager, J.A.; Raffeld, M.; Hills, R.K.; Jaffe, E.S. Age-related EBV-associated lymphoproliferative disorders in the Western population: A spectrum of reactive lymphoid hyperplasia and lymphoma. Blood 2011, 117, 4726-4735. [CrossRef] [PubMed]

76. Saito, S.; Suzuki, K.; Yoshimoto, K.; Kaneko, Y.; Yamaoka, K.; Shimizu, T.; Mori, T.; Okamoto, S.; Kameyama, K.; Amano, K.; et al. Restoration of Decreased T Helper 1 and CD8+ T Cell Subsets Is Associated With Regression of Lymphoproliferative Disorders Developed During Methotrexate Treatment. Front Immunol. 2018, 9, 621. [CrossRef] [PubMed]

77. Ibrahim, H.A.H.; Menasce, L.P.; Pomplun, S.; Burke, M.; Bower, M.; Naresh, K.N. Presence of monoclonal T-cell populations in B-cell post-transplant lymphoproliferative disorders. Mod. Pathol. 2011, 24, 232-240. [CrossRef] [PubMed]

78. Ghia, P.; Prato, G.; Stella, S.; Scielzo, C.; Geuna, M.; Caligaris-Cappio, F. Age-dependent accumulation of monoclonal CD4+CD8+ double positive T lymphocytes in the peripheral blood of the elderly. Br. J. Haematol. 2007, 139, 780-790. [CrossRef] [PubMed]

79. Sakakibara, A.; Kohno, K.; Eladl, A.E.; Klaisuwan, T.; Ishikawa, E.; Suzuki, Y.; Shimada, S.; Nakaguro, M.; Shimoyama, Y.; Takahara, T.; et al. Immunohistochemical assessment of the diagnostic utility of PD-L1: A preliminary analysis of anti-PD-L1 antibody [SP142] for lymphoproliferative diseases with tumour and non-malignant Hodgkin-Reed-Sternberg [HRS]-like cells. Histopathology 2018, 72, 1156-1163. [CrossRef] [PubMed]

80. Nicolae, A.; Pittaluga, S.; Abdullah, S.; Steinberg, S.M.; Pham, T.A.; Davies-Hill, T.; Xi, L.; Raffeld, M.; Jaffe, E.S. EBV-positive large B-cell lymphomas in young patients: A nodal lymphoma with evidence for a tolerogenic immune environment. Blood 2015, 126, 863-872. [CrossRef]

81. Kiyasu, J.; Miyoshi, H.; Hirata, A.; Arakawa, F.; Ichikawa, A.; Niino, D.; Sugita, Y.; Yufu, Y.; Choi, I.; Abe, Y.; et al. Expression of programmed cell death ligand 1 is associated with poor overall survival in patients with diffuse large B-cell lymphoma. Blood 2015, 126, 2193-2201. [CrossRef]

82. Sakakibara, A.; Kohno, K.; Ishikawa, E.; Suzuki, Y.; Shimada, S.; Eladl, A.E.; Elsayed, A.A.; Daroontum, T.; Satou, A.; Takahara, T.; et al. Age-related EBV-associated B-cell lymphoproliferative disorders and other EBV + lymphoproliferative diseases: New insights into immune escape and immunodeficiency through staining with anti-PD-L1 antibody clone SP142. Pathol. Int. 2020, 70, 481-492. [CrossRef] 